\title{
Get your cell-fie
}

\section{Eva Terrado, Elisa Langa, Carlota Gómez-Rincón}

Grado en Farmacia, Facultad de Ciencias de la Salud, Universidad San Jorge, Zaragoza, Spain.

\begin{abstract}
The goal of this project was to enhance the scientific literacy of primary school and Education degree students by Pharmacy learners, using a collaborative work framework and a SERVICE-LEARNING approach, for all of them to accomplish the general and specific learning outcomes related to the subjects involved in this proposal, that is, Biology and General Chemistry from the Degree in Pharmacy and Research and Innovation in Experimental Sciences from the Degree in Education. Assessments of primary school students' learning outcomes revealed that $93 \%$ of the kids were able to increase their knowledge on human cells and also widened their scientific vocabulary in, at least, three to five technical words. Education students valued extremely positive the fact that they could work with a different profile of students and the feedback they received from them. Pharmacy students became aware of the importance of the teacher role in society and highlighted the difficulty they had to face when they tried to explain chemical and biological concepts to a non-scientific audience and especially to kids.
\end{abstract}

Keywords: science literacy; SERVICE-LEARNING; experiential learning; cooperative learning. 


\section{Introduction}

In a highly technified society, such as the one we live in nowadays, scientific literacy is essential to help train citizens to reflect and make appropriate decisions on issues related to science, technology (Solbes and Vilches, 1997) and to their own health. For this reason, from the different educational levels and from a pedagogical and informative approach, we must keep in mind the need to promote and encourage it (UNESCO-ICSU, 1999a-b).

Scientific literacy has to be interpreted as the addition of a triple dimension, the cognitive dimension (know science), the procedural dimension (do science) and attitudinal dimension (value science). On the other hand, we have to take into account that this scientific literacy must be for everybody, without excluding anyone, and always associated with the educational principles of comprehensiveness and equity. This premise is also linked to making "science in school" more accessible, interesting and meaningful. Teaching science is an invaluable instrument to awaken curiosity, develop critical thinking and encourage creativity in our students (Sabariego and Manzanares, 2006).

The active transmission of knowledge is considered the most efficient way to train highly qualified professionals. Therefore, the search for methodologies that allow effective learning is fundamental in current teaching practice (Abadía et al., 2011).

The use of participatory methods developed in groups (cooperative learning) enhances the integration of the acquired knowledge. On the other hand, if the activities are framed in the so-called "experiential learning", then the learning process becomes meaningful (Palos, 2010). One of these latest approaches is the SERVICE-LEARNING (SL) because the students significantly learn while they take part in activities that are useful for the community. The SL considers experience, reflection, and reciprocity as fundamental pillars to promote social and civic responsibility in the student, besides the acquisition of knowledge and professional skills (Eyler and Giles, 1999).

The main purpose of any University should be to serve society through the creation and transmission of knowledge, as well as the education of people to become expert and honest professionals. In this line, one of Universidad San Jorge's main institutional functions is contributing to social development from different areas. Therefore, it is committed to fighting against social exclusion by participating in solidary tasks from teaching and research. The impact on the scientific literacy of society through innovative SL projects constitutes a priority task aligned with the mission, vision, and values of Universidad San Jorge. 


\section{Objective}

According to what we mentioned above, the goal of this project was to enhance the scientific literacy of primary school and Education degree students by Pharmacy learners, using a collaborative work framework and a SL approach, for all of them to accomplish the general and specific learning outcomes (LO) related to the subjects involved in this proposal.

\section{Participants}

All participants live in Zaragoza, Spain. These participants can be divided into two main groups:

a) Three teachers from Pharmacy (Subjects: Biology and General chemistry) and one teacher from Education (Subject: Research and Innovation in Experimental Sciences) degrees from Universidad San Jorge (USJ)

b) Students:

b.1.) Students with scientific background:

Fifty-four students from the $1^{\text {st }}$ year of the Pharmacy degree (Subjects: Biology and General Chemistry) from USJ

b.2.) Students without scientific background:

- University undergraduate level: Fourteen students from Education (Subject: Research and Innovation in Experimental Sciences, $3^{\text {rd }}$ year) from USJ

- Primary school level: Seventy-five students from $3^{\text {rd }}$ year of one public primary school, CEIP Marie Curie.

\section{Tasks and methodology}

First of all, the teachers of the 3 subjects involved in the project had to design the workshops for their students, based on the general and specific learning outcomes every group of students had to accomplish.

In the following sub-sections and on Table 1, the different tasks and workshops are explained together with their content, students involved and duration.

\subsection{Start-up workshop}

Task 1: First of all, Pharmacy students on the one hand, and Education students, on the other hand, all of them in groups of four, had separately their first workshop. They all had to answer two key questions with no online, book or teacher help, i) what is a cell? and ii)what are the cells made of? 
Task 2: Pharmacy students were later taught -by the teacher- how to extract their cells from their own saliva and observe them under the microcope.

Task 3: To finish this initial workshop every group of future pharmacists and every group of future teachers had to write a report in PADLET format with the answers to the previous questions.

\subsection{Cell and Microscope workshop for undergraduates}

Task 4: Pharmacy and Education students worked then all together, in mixed groups of four, and the former showed their answers to the key questions to the later. In the same way, Education students shared with the future pharmacists their information.

Both groups of students worked collaboratively to adjust the specialized key answers to be understood by kids or any non-specialized audience but without losing the scientific rigor.

Task 5: In addition to task 4, the future pharmacists led a second one where the Education students learnt how to extract their own cells from saliva and how to use the microscope to observe them.

Task 6: Right after that, Education students had to i) plan a workshop for primary school kids to explain the key answers mentioned before and to teach how to get their own cells from saliva to be observed under the microscope (assessable product 1), and ii) design and create all the educational materials they were to use in this final workshop (assessable product 2). The contents were reviewed by Pharmacy students to check if Education students really understood the concepts. Likewise, Pharmacy students had to record a oneminute video (assessable product 3), explaining the key answers, to be played before the workshop in the primary school to support pre-service teachers' performance.

In these first workshops (tasks 1 to 6), all their teachers were present but they didn't interact with the students; they were only assessing their performance.

At the end of task 6, teachers reviwed students'material before using it with the primary school kids and gave a report to their learners.

\subsection{Cell-fie workshop}

Tasks 7: When the didactic materials were prepared, all the undergraduate students and their teachers went to the primary school to implement the workshop with the 8-year-old kids. This time, the Education students supported the Pharmacy students with explanations for kids and Pharmacy students supported their colleagues in case they needed some help with technical specifications.

The workshop finished with a picture of every kid's cells (cell-fie) that teachers glued onto a card, what we called the "scientist card" (figure 1). 
Due to the elevated number of primary school kids, task 7 had to be done in three different sessions of 45 min each to guarantee the quality of the workshop.

Once again, the teachers didn't interact with the students to be able to carry out a second assessment of their performance.

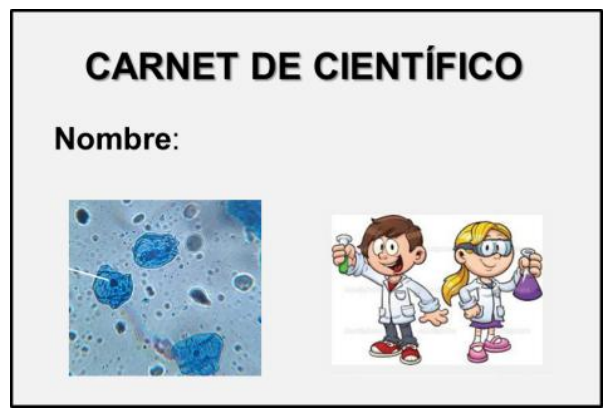

Figure 1. Scientific card with the cell-fie given to the primary school kids

\section{Learning outcomes to achieve and their assessment}

Through this project all undergraduate students worked on the achievement of the following general learning outcomes:

- LO-1: Applying creativity and innovation in their decisions

- LO-2: Managing conflict with respect and empathy

- LO-3: Explaining complex/technical/specialized concepts into easier/more common ones

- LO-4: Communicating concepts efficiently

These learning outcomes were assessed through rubrics the students knew beforehand. Every student was evaluated by her/himself, by their collegues and by the teachers. This evaluation took place twice, after task 6 and after task 7 .

The specific learning outcome for Pharmacy students was:

- LO-5: Applying the knowledge about intermolecular forces on cell biology topics

This learning outcome was evaluated through an opened-ended question which answer had to be developed by the students. This assessment was done at the end of the project.

The specific learning outcome for Education students was:

- LO-6: Designing teaching and learning projects in collaboration with other colleagues from the same or different knowledge areas 
Table 1. Tasks, members involved, content and duration for the different workshops of the current project.

\begin{tabular}{|c|c|c|c|}
\hline Task & Members involved & Content & Duration \\
\hline 1 & $\begin{array}{l}\text { Pharmacy students } \\
\text { Education Students }\end{array}$ & $\begin{array}{l}\text { They had to answer two key questions with } \\
\text { no online, book or teacher help, i) what is a } \\
\text { cell? and ii)what are the cells made of? }\end{array}$ & $2 \mathrm{~h}$ \\
\hline 2 & Pharmacy Students & $\begin{array}{l}\text { They were taught -by the teacher- how to } \\
\text { extract their cells from their own saliva and } \\
\text { observe them under the microcope }\end{array}$ & $1 \mathrm{~h}$ \\
\hline 3 & $\begin{array}{l}\text { Pharmacy students } \\
\text { Education students }\end{array}$ & $\begin{array}{l}\text { Every group of future pharmacists and } \\
\text { every group of future teachers had to write } \\
\text { a report in PADLET format with the } \\
\text { answers }\end{array}$ & $1 \mathrm{~h}$ \\
\hline 4 & $\begin{array}{l}\text { Pharmacy students } \\
\qquad+ \\
\text { Education students }\end{array}$ & $\begin{array}{l}\text { Didatic transposition: Both groups of } \\
\text { students worked collaboratively to adjust } \\
\text { the specialized key answers to be } \\
\text { understood by kids or any non-specialized } \\
\text { audience but without losing the scientific } \\
\text { rigor. }\end{array}$ & $2 \mathrm{~h}$ \\
\hline 5 & $\begin{array}{l}\text { Pharmacy students } \\
\qquad+ \\
\text { Education students }\end{array}$ & $\begin{array}{l}\text { Didatic transposition: Pharmacy students } \\
\text { teach Education students how to extract } \\
\text { their cells from their own saliva and } \\
\text { observe them under the microcope }\end{array}$ & $2 \mathrm{~h}$ \\
\hline 6 & $\begin{array}{c}\text { Pharmacy students } \\
+\end{array}$ & $\begin{array}{l}\text { Creation of the didactic material for the } \\
\text { primary school workshop }\end{array}$ & $4 \mathrm{~h}$ \\
\hline & Education students & & \\
\hline 7 & $\begin{array}{l}\text { Pharmacy students } \\
\qquad+ \\
\text { Education students } \\
+\end{array}$ & $\begin{array}{l}\text { Cell-fie workshop, where Pharmacy and } \\
\text { Education Students teach primary school } \\
\text { kids the cell theory and how to extract their } \\
\text { cells from their own saliva and observe } \\
\text { them under the microcope. }\end{array}$ & $3 \times 45 \min$ \\
\hline & Primary school students & & \\
\hline
\end{tabular}

To evaluate this learning outcome, teachers used rubrics, also known beforehand by the students, and they assessed the didactic material created in task 6. 
The suggested learning outcomes established for kids were:

- $\quad$ LO-7: Enhancing scientific literacy

- $\quad$ LO-8: Encouraging kids to be curious and creative

- LO-9: Identifying the cells as bricks of the human body

In this particular assessment a short questionnaire combaining closed-ended and openended questions were used. This evaluation was done right after the final workshop (task 7).

Apart form the learning outcomes assessment, a satisfaction survey was used to identify the strengths and weaknesses of the project. This satisfaction survey was filled in by Pharmacy, Education and primary school students (an adapted and easier version for these last ones). This survey had closed-ended questions and a final opened-ended question for the students to give their opinion and reasons why they liked or did not like the project.

\section{Results and conclusions}

Assessments of primary school students' learning outcomes (LO-7 to LO-9) revealed that $93 \%$ of the kids were able to increase their knowledge on human cells and to explain, on their own words, what cells were and what they were made of. They also widened their scientific vocabulary in, at least, three to five technical words such as a microscope, cell, lens, etc. At the end of the workshop, around $97 \%$ of kids wanted to be scientists in the future.

Education students'evaluations were very satisfactory, being average marks on assessable LO-1 to LO-4 and LO-6 around 8.7-9.2 out of 10.0. They valued extremely positive the fact that they could work with a different profile of students and the feedback they received from them. They were also very satisfied with the practical experience with a microscope, which found enormously useful for their training.

On the other hand, Pharmacy students obtained average marks on assessable LO-1 to LO-4 and LO-5 ranging from 8.0-9.0 out of 10.0. After these workshops, they became aware of the importance of the teacher role in society. They also highlighted the difficulty they had to face when they tried to explain chemical and biological concepts to a non-scientific audience and especially to kids and how useful the support from the pre-service teachers was.

\section{References}

Abadía-Valle, A. R., Muñoz Gonzalvo, M. J., Soteras, F. (2011). ¿Existen alternativas a las clases magistrales? Una experiencia en Fisiología Ocular del grado de Óptica y Optometría. Arbor, 187(3), 189-194. 
Eyler, J., Giles, D. E., Astin, A. W. (1999). Where's the Learning in Service-Learning? San Francisco: Jossey-Bass.

Palos, J. (2010). ¿Por qué hacer actividades de Aprendizaje Servicio? Aprendizaje Servicio (ApS). Educación y compromiso cívico (pp.151-161). Barcelona: Graò

Sabariego, J. M. Manzanares, M. (2006). Alfabetización científica. Congreso Iberoamericano de Ciencia, Tecnología, Sociedad e Innovación CTS+I. Ciudad de México (México), 19 junio -23 junio

Solbes, J., Vilches, A., (1997). STS interactions and the teaching of Physics and Chemistry. Science Education, 81(4), 377-386.

UNESCO-ICSU (1999-a) Declaración de Budapest sobre la Ciencia y el uso del saber científico. Conferencia Mundial sobre la Ciencia para el siglo XXI: Un nuevo compromiso, Budapest (Hungria), 26 junio - 1 julio

UNESCO-ICSU (1999b). Proyecto de programa en pro de la ciencia: Marco general de acción. Conferencia Mundial sobre la Ciencia para el siglo XXI: Un nuevo compromiso, Budapest (Hungria), 26 junio - 1 julio de 1999. 